\title{
Karakteristik Umkm Pengepul Dan Bandar Barang Bekas Pendekatan Fenomenologis (Studi Kesuksesan Orang Madura Sebagai Pengepul, Bandar barang Bekas Di Keputih Surabaya)
}

\author{
Sutarmin ${ }^{1}$, Wiwik Budiarti²
}

1,2 Universitas Dr Soetomo

\begin{tabular}{|c|c|}
\hline INFO ARTIKEL & Abstract \\
\hline $\begin{array}{l}\text { Sejarah Artikel: } \\
\text { Diterima } \quad: 2020 \\
\text { Diperbaiki : } 2020 \\
\text { Disetujui } \quad: 2020\end{array}$ & \multirow[b]{2}{*}{$\begin{array}{l}\text { This study aims to describe the characteristics of the Micro, Small and } \\
\text { Medium Enterprises of the Madura Community as Collectors, Bandar } \\
\text { in the management of waste and used goods in the Keputih Area of } \\
\text { Surabaya and to determine the description of the relationship between } \\
\text { Collectors and Bandar in the management of waste and used goods in } \\
\text { the Keputih Area of Surabaya. This qualitative research was conducted } \\
\text { in three stages of analysis. First Scaling Measurement, Second } \\
\text { Empirical Generalization, Third Logical Induction. Phenomenological } \\
\text { research seeks to understand the meaning of an experience and the } \\
\text { perspective of participants. Broadly speaking, the entrepreneurial } \\
\text { interpretation of the Collectors community, the used goods / garbage } \\
\text { dealer from Madura is people who dare to try and have a strong } \\
\text { determination; have a strong mentality; Maduranesse are able to work } \\
\text { on every business for years, whether they are forced or not; They } \\
\text { always work hard and never give up every effort; they uphold } \\
\text { cooperation and good relations that are always strong; They are the } \\
\text { type of entrepreneur who does not easily give up on their fate, starting } \\
\text { as scavengers until they become dealers; the majority of used goods } \\
\text { collectors do not receive higher education, but they have an income that } \\
\text { is comparable to or even exceeds that of people who have higher } \\
\text { education; Scavengers are organized by a number of Bandar or } \\
\text { Collectors, A boss, both the small boss and the big boss recruits a } \\
\text { number of potential scavengers, they are invited and offered to become } \\
\text { members of the group, they get loans from collectors. Participants in } \\
\text { this research are collectors and dealers of garbage or used goods in the } \\
\text { Keputih of the city of Surabaya. While the number of participants is } 25 \\
\text { people who work as scavengers, collectors and used goods dealers and } \\
\text { have had this business for years; The criteria used are informants who } \\
\text { have lived above 10 years; The interviewed informants were collectors } \\
\text { and dealers. }\end{array}$} \\
\hline $\begin{array}{l}\text { Keywords: } \\
\text { Mentally strong, enthusiastic, } \\
\text { hard work and never giving up } \\
\text { are the keys to success to } \\
\text { progress and generate high } \\
\text { economic value }\end{array}$ & \\
\hline & Abstraks \\
\hline $\begin{array}{l}\text { Kata Kunci: } \\
\text { Kuat Mental, Kuat Semangat, } \\
\text { Kerja keras dan Pantang } \\
\text { Menyerah adalah kunci sukses } \\
\text { untuk maju dan menghasilkan } \\
\text { nilai ekonomi tinggi }\end{array}$ & $\begin{array}{l}\text { Penelitian ini bertujuan untuk Untuk mengetahui gambaran } \\
\text { karakteriktikUsaha Mikro Kecil Menengah bagi Masyarakat } \\
\text { Madura sebagai Pengepul dan Bandar dalam pengelolaan } \\
\text { barang bekasdi Keputih Surabaya. Penelitian Kualitatif ini } \\
\text { dilakukan dengan tiga tahap analisis Pertama Scalling }\end{array}$ \\
\hline
\end{tabular}




\begin{tabular}{|l|l|}
\hline DOI: & $\begin{array}{l}\text { Measurement , Kedua Empirical Generalization, Ketiga Logical } \\
\text { Induction P. Penelitian fenomenologis berusaha memahami } \\
\text { makna dari sebuah pengalaman dan perspektif partisipan. } \\
\text { Secara garis besar interpretasi wirausaha masyarakat Pengepul, } \\
\text { Bandar barang bekas dari Madura adalah : orang yang berani } \\
\text { mencoba dan mempunyai tekad yang kuat; mempunyai mental } \\
\text { kuat; orang madura mampu bertahun-tahun menggeluti setiap } \\
\text { usaha, terlepas dari terpaksa atau tidak terpaksa; Mereka selalu } \\
\text { kerja keras pantang meyerah setiap berusaha; mereka } \\
\text { menjunjung tinggi kerja sama dan hubungan baik yang selalu } \\
\text { melekat kuat; Mereka adalah tipe wirausaha yang tidak mudah } \\
\text { menyerah pada nasib, mulai sebagai pemulung sampai } \\
\text { meningkat menjadi bandar; mayoritas para pengepul barang } \\
\text { bekas tidak mempunyai pendidikan tinggi, tapi mereka } \\
\text { mempunyai penghasilan yang sebanding atau bahkan melebihi } \\
\text { penghasilan orang yang mempunyai pendidikan tinggi; } \\
\text { pemulung diorganisir oleh sejumlah Bandar atau Pengepul. } \\
\text { Seorang bos, baik bos kecil maupun bos besar merekrut } \\
\text { sejumlah calon pemulung, mereka diajak dan tawari menjadi } \\
\text { anggota kelompok, mereka mendapat pinjaman dari para } \\
\text { pengepul. Partisipan dalam penelitian ini adalah masyarakat } \\
\text { pengepul dan bandar barang bekas di keputih kota Surabaya. } \\
\text { Sedangkan jumlah partisipan sebanyak 25 orang yang } \\
\text { menggeluti pekerjaan sebagai pemulung, pengepul maupun } \\
\text { bandar barang bekas dan sudah bertahun-tahun mempunyai } \\
\text { usaha tersebut. Kriteria yang digunakan adalah Informan yang } \\
\text { sudah menetap 10 tahun ke atas; Informan yang diwawancarai } \\
\text { adalah Pengepul dan Bandar. }\end{array}$ \\
\hline Korespondensi: \\
Nama: Sutarmin \\
Email: sutarmin2415@gmail.com
\end{tabular}

\section{PENDAHULUAN}

Menurut Statistik lingkungan Hidup Indonesia (2018) Tahun 2016 jumlah timbulan sampah di Indonesia mencapai 65.200.000 ton per tahun dengan penduduk sebanyak 261.115.456 orang. Proyeksi penduduk Indonesia menunjukkan angka penduduk yang terus bertambah dan tentunya akan meningkatkan jumlah timbulan sampah. Harus dilakukan suatu upaya agar Target Sustainable Development Goals(SDGs) 12.5 yang menyatakan negara secara substansial mengurangi timbulan sampah melalui pencegahan, pengurangan, daur ulang, dan penggunaan kembali dapat dicapai. Langkah pemerintah tertuang dalam Pepres 97 Tahun 2017 yang menargetkan pengurangan sampah rumah tangga dan sampah sejenis sampah rumah tangga sebesar 30 persen dan penanganannya sebesar 70 persen.
Pertambahan jumlah penduduk adalah salah satu faktor naiknya jumlah timbulan sampah. Tahun 2025 perkiraan jumlah penduduk Indonesia adalah sebesar 284.829.000 orang atau bertambah 23.713.544 dari tahun 2016. Jika diasumsikan jumlah sampah yang dihasilkan per tahun adalah sama maka jumlah sampah yang akan bertambah adalah sebesar 5.928.386 ton (tahun 2016 jumlah timbulan sampah di Indonesia mencapai 65.200.000 ton per tahun dengan penduduk sebanyak 261.115.456 orang, KLHK dan Kementrian Perindustrian dalam World Bank). Tahun 2017, produksi sampah per hari yang cukup tinggi terjadi di Pulau Jawa, antara lain Surabaya menghasilkan sampah 9.896,78 m3 per hari dan Jakarta menghasilkan sampah sebanyak 7.164,53 m3, sedangkan di luar Pulau Jawa, antara lain Makasar menghasilkan 6.485,65 m3 per hari selanjutnya Denpasar, Manado, dan Medan secara berurutan menghasilkan 
sampah 3.657,20; 2.064,00; dan 1.892,00 m3 per hari.

Dari kondisi diatas pemulung, pengepul dan Bandar barang bekas mempunyai peran dalam mengurangi timbulan sampah yang ada di Surabaya.Pemulung adalah pengais langsung di lokasi tertentu, pengais yang bergerak (mobile), pengepul adalah kolektor barang bekas yang di dapat dari para pengais/pemulung), dan pendaur ulang barang bekas, Bandar adalah penampung barang bekas dari kolektor. Para pemulung dapat mengurangi sampah khususnya sampah anorganik dan sangat bermakna dalam menekan debit sampah di Kota Surabaya.

Peran tersebut tidak terlepas dari munculnya komunitas masyarakat pemulung, pengepul dan bandar sampah di kota surabaya.Dan tidak kalah berperan adalah bentuk usaha kecil atau kelompok penampungan/pengepul barang bekas yang ada di Keputih Surabaya.Keputih dahulunya sebagai Tempat Pembuangan Akhir untuk wilayah Surabaya sehingga banyak sekali ditemukan komunitas pemulung, pengepul dan Bandar sampah sampai saat ini, meskipun sekarang TPA sudah dialih fungsikan ke Daerah Benowo Surabaya. Keputih mempunyai merupakan eks TPA yang sampai sekarang masih ada wilayah yang terkenal usaha kecil barang bekas bagi masyarakat pemulung, pengepul dan Bandar - Usaha kecil yang bergerak pada bidang penampungan barang bekas, yang beranggotakan Pemulung, Pengepul dan Bandar barang bekas. Jenis barangbekas yang ditampung pada kelompok usaha kecil pengepul barang bekas ini adalah besi tua, kertas dan limbah/sampah plastik.

Mayoritas pemulung, pengepul dan bandar adalah dari Madura. Migrasi juga membuat sebaran warga Madura hampir merata di sepanjang daerah Keputih atau Surabaya utara sampai wilayah Surabaya timur. Kondisi geografis Madura juga memberi kontribusi dalam membentuk watak tegas, keras dan ulet dalam berusaha. Mereka memiliki sebuah falsafah 'ango' an pote tolang etembang pote matah, artinya lebih baik putih tulang dibandingkan putih mata. Orang Madura tidak akan sanggup menanggung malu, maka juga tidak akan mempermalukan orang lain. Sifat seperti inilah yang pada akhirnya melahirkan tradisi kuat di Madura.

Streotipe orang madura yang keras, berani, ulet dan hemat sedangkan hasil kajian BAPPEDA Jawa Timur, diperkirakan 75\% masyarakat Madura tinggal diluar Madura. Karakter ini termanifestasikan ketika harus merespon segala sesuatu yang dihadapi dalam kehidupan sehari-hari. Dalam kontek ini berarti bahwa nilai- nilai Madura membuka peluang bagi ekspresi individual secara lebih transparan. Karakter positif orang madura adalah untuk berhasil menjadi kaya harus berani berpetualang. Keputusan untuk terjun dan memilih profesi sebagai seorang wirausaha didorong oleh beberapa kondisi, antara lain pertama orang tersebut lahir atau dibesarkan dalam keluarga yang memiliki tradisi yang kuat dibidang usaha (confidence modalities), Kedua orang tersebut berada dalam kondisi yang menekan, sehingga tidak ada pilihan lain bagi dirinya selain menjadi wirausaha (tension modalities), ketiga seseorang yang memang mempersiapkan diri menjadi pengusaha (emotion modalities).

Berdasarkan latar belakang di atas peneliti mencoba mengawali salah satu UMKM yang mayoritas di anggap sepele oleh sebagian orang, justru memberikan nilai positif dalam menghasilkan financial sebagai sumber nafkah untuk keluarga. Usaha tersebut adalah pengelolaan barang bekas yang dilakukan mayoritas orang-orang Madura di Keputih Surabaya.Oleh karena itu barang bekas sudah tidak lagi dipandang sebelah mata karena barang bekas menghasilkan pendapatan yang jumlahnya tidak bisa dibilang sedikit ketika ditangani oleh orang - orang yang kreatif. Oleh karena itu penulis ingin meneliti tentang “Karakteristik UMKM Pengepul dan Bandar Barang Bekas Pendekatan Fenomenologis (Studi Kesuksesan Orang Madura Sebagai Pengepul, Bandar Barang Bekas di Keputih Surabaya)"

\section{TINJAUAN PUSTAKA \\ Pengertian Sampah}

Menurut kamus lingkungan dalam Madanitec (2011) dinyatakan bahwa sampah adalah bahan yang tidak mempunyai nilai atau tidak berharga untuk digunakan secara biasa atau khusus dalam produksi atau 
pemakaian; barang rusak atau cacat atau materi berkelebihan atau buangan. Sehingga hal ini juga dapat menambah pendapatan untuk pengepul sampah. Menurut Mifbakhuddin dkk (2010) sampah merupakan materi atau zat, baik yang bersifat organik maupun anorganik yang dihasilkan dari setiap aktivitas manusia. Aktivitas bisa berupa rumah tangga, industri, maupun kegiatan komersial. Dalam Neolaka (2008) sampah adalah segala sesuatu yang tidak diperlukan lagi oleh pemiliknya. Sampah ada yang mudah membusuk dan ada yang tidak mudah membusuk. Sampah yang mudah membusuk (garbage) adalah zat organik seperti: sisa daging, sisa sayuran,daundaunan, sampah kebun dan lainnya. Sampah yang tidak mudah membusuk (refuse) adalah zat anorganik seperti: kertas, plastik, logam, karet, abu, gelas, bahan bangunan bekas, dan lainnya. Terdapat pula sampah berbahaya atau bahan beracun berbahaya (B3), sampah berbahaya ini terjadi dari zat kimia organik dan anorganik serta logam-logam berat, yang umumnya berasal dari buangan industri. Menurut definisi World Health Organization (WHO) sampah adalah sesuatu yang tidak digunakan, tidak dipakai, tidak disenangi atau sesuatu yang dibuang yang berasal dari kegiatan manusia dan tidak terjadi dengan sendirinya (Chandra, 2006).

\section{Sumber Sampah}

Menurut Suparno (2013) sampah bisa dari hasil kegiatan alam atau kegiatan manusia. Asal sampah digolongkan berdasarkan sampah yang dihasilkan, diantaranya sebagai berikut:

1. Sampah dari makhluk yang sudah mati: (a). Binatang, Di hutan-hutan bangkai binatang tidak menjadi persoalan. Akan tetapi di daerah permukiman bangkai itu harus segera dikuburkan. Jika tidak dikuburkan akan menggangu lingkungan di sekitarnya karena bangkai itu akan menumbuhkan bau yang sangat menusuk hidung. (b). Tumbuh-tumbuhan, di desa, daun-daun yang berguguran dalam perkarangan dapat dijadikan humus, asal jangan dihanyutkan ke dalam air sungai.Akan tetapi di kota-kota besar yang di kedua tepi jalannya banyak pohon, daundaun yang berguguran menjadi tugas pemerintah daerah atau bagian kebersihan kota untuk menyapunya sehingga keadaan kota tetap bersih dari sampah.

2. Sampah rumahtangga, Sampah rumah tangga dapat berupa: (1) Sampah basah, yang berasal dari dapur sisa-sisa makanan. (2) Sampah kering, diantaranya daun- daun, pohon, bekas pemotongan rumput, kertas dan bahan-bahan plastik. (3) Barang-barang bekas, diantaranya kaleng, botol, pecahan gelas, karton, dan bekas pakaian.

3. Sampah dari kompleks perumahan, Ada kompleks perumahan yang berdiri sendiri sehingga masalah pembuangan sampah harus diusahakan sendiri. Penanganan sampah ini dapat diserahkan pada pihak swasta. Sampah diangkut ke tempat penampungan, lalu diolah lebihlanjut.

4. Sampah pasar, Pembuangan sampah dari sampah pada umumnya dilakukan oleh pemerintah daerah.

5. Sampah dari kompleks industri, Industri, perusahaan, atau pabrik, mengolah bahan baku menjadi bahan baku lainnya atau menjadi bahan konsumen. Proses pengolahan itu akan menghasilkan sampah. Pada umumnya industri berdiri sendiri sehingga masalah sampah harus diselesaikan sendiri. Oleh karena itu, setiap industri harus mengetahui banyak, dan macamnya sampah yang dihasilkan.

6. Sampah dari kota, Sampah kota berasal dari rumah tangga, pasar, atau daerah perdagangan, jalan-jalan, dan gedunggedung perkantoran dan sekolah-sekolah, serta tempat-tempat lainnya.

7. Sampah dari pedesaan, Sampah di pedesaan selain berasal dari rumah tangga, juga dari halaman atau perkarangan.

\section{Jenis-Jenis Sampah}

Komposisi sampah mencakup persentase dari komponen pembentuk sampah yang secara fisik dapat dibedakan dalam tiga jenis yaitu sampah organik, sampah anorganik dan sampah campursari. Komposisi sampah ini dapat digunakan sebagai bahan pertimbangan untuk menentukan pilihan kelayakan pengolahan sampah khususnya daur ulang dan pembuatan kompos serta kemungkinan penggunaan gas landfill sebagai energi elternatif. Menurut Achmad Zubair (2011) Sampah pada umumnya di bagi 2 jenis 
a. Sampah Organik, Yaitu sampah yang mengandung senyawa-senyawa organik, karena itu tersusun dari unsur-unsur seperti C, H, O, N dll. Umunya sampah organik dapat terurai secara alami oleh mikro organisme. Contohnya, sisa makanan, karton, dan daun-daun.

b. Sampah Anorganik, Yaitu sampah yang bahan kandungannya non organik umumnya sampah ini sangat sulit terurai oleh mikro organisme. Contohnya: plastik, kaleng, kaca, dan logam-logam. membantu pemerintah dalam menagani sampah yang berada di TPA.

Menurut Ikhsandri dkk (2014) sampah terdiri dari:

a. Sampah Basah, Sampah jenis ini dapat diurai atau biasa dikatakan membusuk. Contohnya ialah sisa makanan, sayuran, potongan hewan, daun kering dan semua materi yang berasal dari makhluk hidup.

b. Sampah Kering, Sampah yang terdiri dari logam seperti besi tua, kaleng bekas dan sampah kering nonlogam seperti kayu, kertas, kaca, keramik, batu- batuan dan sisa kain.

c. Sampah Lembut, Contoh sampah ini adalah debu dari penyapuan lantai rumah, gedung, penggergajian kayu dan abu dari rokok atau pembakaran kayu.

d. Sampah Besar, Sampah yang terdiri dari buangan rumah tangga yang besar-besar seperti meja, kursi, kulkas, televisi, radio, dan peralatan dapur.

e. Sampah Komersial, Sampah yang berasal dari kegiatan komersial seperti pasar, pertokoan, rumah makan, tempat hiburan, penginapan, bengkel dan kios. Demikian pula dari institusi seperti perkantoran, tempat pendidikan, tempat ibadah dan lembagalembaga nonkomersial lainnya.

f. Sampah Bangunan, Sampah yang berasal dari kegiatan pembangunan termasuk pemugaran dan pembongkaran suatu bangunan seperti semen, kayu, batu-bata dan genting.

g. Sampah FasilitasUmum, Sampah ini berasal dari pembersihan dan penyapuan jalan, trotoar, taman, lapangan tempat rekreasi dan fasilitas umum lainnya. Contohnya ialah daun, ranting, kertas pembungkus, plastik dan debu. membantu pemerintah dalam menagani sampah yang berada di TPA.

\section{Dampak positif dari sampah}

Menurut Marliani, Novi (2014) dampak positif dari sampah yaitu:

a. Dampak Sosial : (1). Sampah bisa menjadi lapangan kerja bagi sebagian orang.Misalnya pemulung, pengepul barang bekas, masyarakat yang bekerja di pengepulan barang bekas maupun orangorang yang bekerja membersihkan sampah sebagai petugas dinas kebersihankota. (2). Memberi pengaruh dan dorongan terhadap warga sekitar (pada tingkat rumah tangga) untuk melakukan pemilahan sampah, walaupun perubahan pola perilaku tersebut tidaklah mudah karena berkaitan dengan cara perubahan kultur dan cara pandang.

b. Dampak Ekonomi, Keberadaan sampah dapat meningkatkan ekonomi dengan mendatangkan keuntungan guna memenuhi kebutuhan rumah tangga dan menambah uang saku bagi anak.

c. Dampak Lingkungan, Dengan adanya pengepulan sampah, keberadaan sampah lebih berarti karena lebih baik dijual dari pada terbuang secara sia-sia atau dibakar. Oleh karena itu, keberadaan pengepul sampah juga dapat meningkatkan kenyaman lingkungan dengan semakin berkurangnya warga yang membakar sampah.

\section{Definisi Pengepul Sampah.}

Menurut Saputra, sangga dkk (2017) pengepul sampah merupakan bagian dari sektor informal yang bergerak dalam pengumpulan dan perdagangan sampah layak jual, dalam keberhasilan usaha pengepul sampah dapat dilihat dari tingkat laba yang dihasilkan pertahun. Laba merupakan selisih antara penghasilan penjualan di atas semua biaya dalam periode tertentu, laba sebesar pengahasilan penjualan dikurangi semua biaya. Keberhasilan pengepul sampah dapat dipengaruhi oleh beberapa faktor diantaranya ialah, motivasi, pengalaman, tingkat pendidikan, usia, modal usaha, dan lokasi usaha.

Suparno (2013) Pengambilan sampah oleh sektor informal menjadi salah satu usaha untuk mengurangi jumlah sampah. Sektor informal ini memiliki jaringan yang cukup luas meliputi pemulung, pengepul, sub suplayer, dan suplayer. Sampah yang diambil 
oleh pemulung berupa sampah kertas, plastik, logam, dan gelas. Para pemulung merupakan ujung tombak proses daur ulang di Indonesia untuk memanfaatkan kembali sampah. Dari kegiatan pemulung ini akan bermuara pada industri daur ulangsampah.

Achmad Zubair (2011) Kehadiran sektor informal, seperti para pengepul sampah dan pemulung dalam kegiatan pengelolaan sampah memberikan peran yang cukup besar terhadap berkurangnya sampah yang harus diolah di Tempat Pembungan Akhir (TPA). Peran sektor informal tersebut dapat meningkatkan kebersihan lingkungan, mengurangi sampah dan meminimalisasi kerusakan lingkungan di TPA. Pekerjaan memulung sampah dinilai positif karena keberadaan pemulung dapat memberikan kontribusi bagi pemerintah terhadap kebersihan serta kontribusi dalam menciptakan lapangan kerja. Dan yang utama adalah dapat mengurangi volume sampah di TPA dan untuk mengawali proses daurulang.

Karakteristik Kewirausahaan

Ahli lain, seperti M. Scarborough dan Thomas W. Zimmerer:1993.mengemukakan delapan karakteritik kewirausahaan sebagai berikut :

1. Desire for responsibility, memiliki rasa tanggung jawab atas usaha-usaha yang dilakukannya.

2. Preference for moderate risk, lebih memilih resiko moderat, artinya selalu menghindari resiko, baik yang terlalu rendah maupun terlalu tinggi.

3. Confidence in their ability to success, memiliki kepercayaan diri untuk memperoleh kesuksesan.

4. Desire for immediate feedback, selalu menghendaki umpan balik dengan segera.

5. High level of energy, memiliki semangat dan kerja keras untuk mewujudkan keinginannya demi masa depan yang lebih baik.

6. Future orientation, berorientasi serta memiliki perspektif dan wawasan jauh ke depan.

7. Skill at organizing, memiliki keterampilan dalam mengorganisasikan sumber daya untuk menciptakan nilai tambah.

8. Value of achievement over money, lebih menghargai prestasi daripada uang.
Buchari Alma(2010) Keberhasilan atau kegagalan wirausaha sangat dipengaruhi oleh sifat dan kepribadiannya. Kepribadian wirausaha terletak pada : (a) Kepercayaan diri (b) Kemampuan mengorganisasi (c) Kreativitas (d). Menyukai tantangan.

Dari beberapa pendapat tersebut dapat disimpulkan Ciri kewirausahaan yaitu: Motivasi berprestasi; Kemandirian; Kreativitas; Pengambilan resiko (sedang); Keuletan; Orientasi masa depan; Komunikatif dan reflektif; Kepemimpinan; Locus of Contro; Perilaku instrumental; Penghargaan terhadap uang.

\section{METODE PENELITIAN \\ Pendekatan penelitian}

Penelitian ini merupakan penelitian kualitatif, sebagaimana dikatakan oleh Ruslan (2006) bahwa penelitian kualitatif dapat dipergunakan untuk penelitian kehidupan masyarakat, sejarah, tingkah laku, fungsional organisasi, peristiwa tertentu, pergerakan-pergerakan sosial, dan hubungan kekerabatan dalam kekeluargaan. Sesuai dengan karakteristik fenomena yang terjadi, penelitian ini menggunakan dasar teori fenomenologis. Pendekatan digunakan dalam penelitian ini dengan maksud untuk mengungkap makna yang tersirat dalam perilaku karakteristik kewirausahaan Masyarakat Pengepul dan Bandar di Daerah Keputih Surabaya.

\section{Rancangan Penelitian}

Penelitian ini menggunakan pendekatan kualitatif yang berbentuk study kasus untuk mendapatkan pemahaman yang mendalam sesuai fonomena.Data yang terkumpul dipelajari sebagai satu kesatuan yang tujuannya adalah untuk mengembangkan pengetahuan yang mendalam mengenai objek yang diteliti:

Emzir (2016) Pengumpulan Data(Wawancara, Observasi, Dokumentasi, Study) $\rightarrow$ Display Data(Menyusun dan menampilkan Data apa adanya) $\rightarrow$ Reduksi Data (Proses pemilihan,penyederhanaan, sesuai kebutuhan data) $\rightarrow$ Verifikasi Data(Merumuskan kesimpulan sebagai jawaban atas pertanyaan penelitian) $\rightarrow$ Analisis Data dan Pembahasan(Interpretasi Data Pembandingan dengan teori dan hasil penelitian 
Fenomenologi) $\rightarrow$ Penyajian $\quad$ Data(Dalam bentuk Narasi, gambar) $\rightarrow$ Saran

\section{Jenis dan Sumber Data}

Sumber data primer : dalam penelitian ini yang menjadi sumber utama adalah masyarakat pengepul dan Bandar di daerah Keputih Surabaya.

Sumber data sekunder: diperoleh dari wawancara (data wawancara dengan pemulung), dokumentasi dan bacaan yang releven mengenai karakteristik kewirausahaan masyarakat Pengepul dan Bandar di daerah Keputih Surabaya.

\section{Teknik Pengumpulan Data}

Teknik Pengumpulan data yang dilakukan dalam penelitian ini adalah melalui Observations (Pengamatan), Wawancara dan Studi Dokumentasi.

1. Observasi, ini dilakukan untuk memperoleh dan mengamati secara langsung sesuatu yang ada pada data terkait dengan karakter wirausaha masyarakat pemulung, pengepul dan bandara sampah di Keputih Surabaya.

2. Wawancara, wawancara lebih terperinci yang berkaitan dengan unsur-unsur karakteristik wirausaha masyarakat Keputih sebagai eks TPA Kota Surabaya.

3. Studi Dokumentasi, Dokumen yang dimaksud diantaranya adalah buku, artikel yang memuat tentang sampah, jurnal yang yang memuat tentang sampah melalui internet yang memuat tentang sampah dan manfaat-manfaat sampah, foto- foto yang digunakan untuk mengambil gambar informan dan saat melakukan wawancara

\section{Uji Keabsahan Data}

Dalam penelitian ini digunakan teknik trianggulasi dengan sumber, trianggulasi sumber dilakukan setelah data yang diperoleh kemudian di analisis yaitu dicek sehingga menghasilkan kesimpulan.

\section{Teknik Pengolahan Data}

Teknik pengolahan data yang dilakukan melalui beberapa tahap Emzir (2016):

1. Scalling Measurement,langkah awal yang harus dilakukan yaitu membuat "Transkrip" atau uraian dalam bentuk tulisan yang rinci dan lengkap mengenai apa yang dilihat dan didengar baik secara langsung.

2. Empirical Generalization,analisis terhadap isi transkrip. Menunjukkan makna-makna yang melekat dalam suatu teks, utamanya makna tersembunyi yang terkandung dalam teks. Menganalisis bagaimana teks berkaitan dengan kehidupan, pengalaman, kenyataan, dan hal-hal yang bermakna tentang subyek penelitian.

3. Logical Induction. dengan mencari pemahaman mendalam terhadap realitas sosial yang diteliti sebagaimana realitas sosial tersebut dipahami oleh subyek penelitian, serta melakukan Interpretasi terhadap makna dibalik perkataan dan tingkah laku subyek penelitian.

\section{HASIL PENELITIAN DAN PEMBAHASAN}

Berdasarkan wawancara dan

observasi yang telah dilakukan, penulis dapat menguraikan beberapa hal cuplikan hasil wawancara:

\section{A. Scalling Measurement:}

Informan I :.... Informan:" wah akeh mas..., intine kudu wani risiko yen usaha, kudu percaya awak, kudusabar, tekun ugo, kudu kerja keras, sing luwih penting ora isin mergo kerjoan sampah mas, barang kotor. Wong iku rak gur nonton saikine mas. Nggak nonton prosese yo opo sampek koyok ngene iki. semangat karo disenengi yen kerjo iku. "Alhamdulillah. Kulo pun saged nebus utang modal neng wong tuwo. Saged tuku omah onok ndeso. Saged nyekolahke anak, ya jalan Allah iku pasti ada saja kalau usaha. .......he..he...he... sing penting dilakoni ae mas. Setiap nekuni usaha iki sak jane akeh pilihan, awak dewe iki kudu iso cerdik lan pintar kanggo milah-milah barang rongsok sing duwe nilai jual tinggi supoyo hasil tinggi...... Sing penting kuasai, kenali jenise barang secara keseluruhan, lan kuncine iku awak dewe iki kudu ngerti jenis besi sing paling murah regone iku maksude kanggo patokan harga saben tuku barang.

Informan II :"... sudah turun temurun pak, saya Cuma meneruskan usaha abah, abah sudah meninggal, jadi saya meneruskan saja. Dulu usaha saya juga sama barang rongsokan. 
Cuma setelah abah tidak ada saya pindah ke Keputih ini;... Karyawan tetap satu orang, yang tiga orang harian atau karyawan lepas;......usaha ini amanah dari abah Pak. Abah sudah nggak ada. Saya lulus dari pondok langsung dinikahkan dengan Ayah sekarang. Suami saya sebenarnya masih saudara. Abah ketemu abah mertua yo langsung dijodohkan; Begini ini sudah seperti mendarah daging, sudah muncul seperti biasanya. Almarhum abah ya sudah ngajari dari kecil, Abah dulu saya akui ulet. Usaha begini ini risikonya besar lho Pak. Karena ketika dapat pesanan barang untuk estimasi harga itu hanya kira-kira. Karena hanya kira-kira kadang-kadang meleset dari perhitungan. Kalau dapat telpon ya Ayah langsung berangkat. Jadi semuanya tanpa timbangan Pak. Hanya kira-kira. Yang rugi itu pada saat dikira-kira ternyata tidak pas; ....Rasa syukur harus diterapkan Pak. Orang usaha harus siap segala risiko. Termasuk risiko rugi, risiko tidak punya uang. Kondisi begini harus pinter-pinter mencari penjual Pak. Tidak kenal capai, kalau ada yang telpon ayah selalu siap saja, untuk melihat barangnya;

Informan III : .....kanggo buka usaha ngene iki di butuhno kerja keras, semangat, seneng, gak isin, yo koyok karo bojo iku mas cintai apa adanya.....h...h...h...h...usaha ini bergulir terus. Saben hari onok ae barang baru yang datang untuk dibeli. persaingan juga ketat tho mas, ojo dikiro nggak onok saingane.Menjadi pengepul barang bekas barang rongsok memang mbutuhno tekad dan berani malu, mergo gak sitik orang sing ragu dan merasa jorok dengan usaha semacam ini. Pertama sing kudu dilakukan adalah memiliki tempat penampungan. Kudu apal rego-rego barang.

Informan IV:... ... kerjoan opo ae harus di seriusi Mas. Ojo setengah-setengah. Saiki iki kudu tekad sing kuat, melakukan kerja kudu dicintai, kerja keras iku modale. Sing penting nggak ngganggu uripe konco, nggak ngganggu uripe tonggo. Yen iso tonggotonggo ndeso kono diajak merantau beno gak lontang lantung onok ndeso mainan HP ae. Arek jaman saiki iku ngerti beres ae, dolanan HP sepedaan kakehan gaya tapi nganggur. Opo meneh aku nonton ponakanku sing iku.
Makane langsung tak pekso kudu kerjo. Sekolah ae wes sering mbolos sampai sampai wong tuwone di panggil pihak sekolah mergo sering mbolos. Lha yo mergo lingkungan mas saiki iki......

......Bisnis barang bekas menurut saya sangat menjanjikan. Risiko ya ada mas. mergone yen tuku besi, aluminium barang-barang sing rusak iku kadang mung estimasi. Usaha iki nggak mengenal musim. Cuaca apa pun, yen limbah plastik tetap melimpah ruah, besi selalu ada, sing penting telaten, semangat, niat yang kuat, ojo isin, ojo males, ojo wedi risiko, optimis, wes to rejeki di depan kita.

B. Empirical Generalization, analisis terhadap isi transkrip.

Informan I :

1. Berani Mencoba dan tekat yang kuat. (...saya mencoba buka usaha sendiri setelah berkeluarga sampai sekarang ini.Alhamdulillah iso lancer sampai saiki)

2. Mental yang kuat (Putar otak mas, opo meneh wektu iku buka usaha dewe...).

3. Berani menghadapi kegagalan atau pantang menyerah pada keadaan...(...awale dodolan bakso keliling tak lakoni berjalan yen gak salah mung 7 bulanan. Bar iku pernah usaha mbukak warung kopi (jaman disik onok TPA mas. Alhamdulillah yo Tutup, hasile nggak cukup kanggo nyukupi kebutuhan saben dinone...)

4. Semangat dan Mencintai Pekerjaaan (...Arepo ngene yo nyaman ae. Yen arep golek kerjoan koyok dadi dosen ha...haaa.haa.. jebol SMP ae nggak mas...).(...semangat karo disenengi yen kerjo iku....)

5. Harus berani risiko kan begitu kalau usaha, harus percaya diri, harus sabar, tekun juga, terutama harus kerja keras. (....Kudu wani risiko yen usaha, kudu percaya awak, sing sabar, tekun ugo, utamane kudu kerjakeras, sing luwih pentingojo isin mergo kerjoan sampah mas, barang kotor,semangat karo disenengi yen kerjo...)

6. Kenali dulu jenis barangnya secara keseluruhan(...kunci nya jika kita lihat contoh di atas tadi adalah kita harus mengenali 
jenis besi yang termurah harganya untuk kita jadikan patokan harga dalam membeli barang)

7. Menekuni Pekerjaan(...Wes 20 tahunan usaha rongsokan...)

8. Harus cerdik dan pintar(...sing pengen awake kuasai, kasarane mas awak dewe iki kudu iso cerdik lan pintar...)

Informan II:

1. Ketelatenan, kesabaran, Ketekunan(...sudah turun temurun pak, saya Cuma meneruskan usaha abah, abah sudah meninggal, jadi saya meneruskan saja.)

2. Bisa Membaca Peluang dan Kerja Keras (Lha kalau hanya mengandalkan dari Surabaya yo tidak dapat apa-apa pak.. Kadang ke Kalimantan, Jambi, Lampung, Bali, Lombok, Sering Ayah yang ke Lombok untuk melihat barangnya. Kadang sampai satu minggu di luar pulau)

3. Merintis Usaha di mulai dari awal dan ditekuni(Iya Pak, Almarhum Abah sudah bertahun tahun sudah menggeluti kerja seperti ini. Abah sudah bertahun-tahun merintis usaha ini, kalau tidak putra-putranya siapa lagi.)

4. Merintis dari keadaan susah, sulit, penuh kerja keras dan Tidak mudah menyerah. (....Kalau Abah merintis dari keadaan susah, sulit dan penuh kerja keras...).

5. Rasa bersyukur (...Kalau penghasilan itu Pak relatif, besar kecilnya tergantung orang menyikapi. Kadang hasil besar ya masih saja merasa kurang, masih mencari sana sini, dan bahkan rasa syukurnya sudah tidak ada lagi...)

6. Berani Menanggung Risiko (Rasa syukur harus diterapkan Pak. Orang usaha harus siap segala risiko. Termasuk risiko rugi, risiko tidak punya uang...)

7. Selalu Kerja Keras (....Kondisi begini harus pinter-pinter mencari penjual Pak. Tidak kenal capai, kalau ada yang telpon ayah selalu siap saja, untuk melihat barangnya.)

Informan III:

1. Sabar menjadi unsur pokok setiap berusaha(...Kerja tempate barang kotor-kotor, panas dilakoni, abot dilakoni, rugi kudu siap, saingan saiki wes akeh. Yen jaman 20 tahun kepungkur....)

2. Percaya diri dan melalui proses Panjang(...Suwe-suwe tak sadari usaha iki iso dadi sebuah peluang usaha yang bisa mendatangkan keuntungan lumayan....)

3. Niat yang kuat, Kerja keras, Pantang menyerah(...buka usaha ngene iki di butuhno kerja keras, semangat, seneng, gak isin....)....(...barang bekas barang rongsok memang mbutuhno tekad dan berani malu, mergo gak sitik orang sing ragu...)

4. Semangat dan tekad yang kuat serta Sabar (Kunci kanggo sukses dalam usaha ini iku sabar, mergo proses iki memang susah.)

Informan IV:

1. Dalam setiap berusaha yang penting punyai mental siap susah jangan siap berhasil (...Merantau diajak koncoku nang Suroboyo, wektu iku kerjo opo ae dilakoni, tukang bangunan yo dilakoni, bakulan yo dilakoni, jualan tahu thek-thek yo dilakoni, nganti pirang-pirang tahun.)

2. Tekat yang kuat dalam setiap Usaha (...Akhire kudu nekad merantau neng Suroboyo sampai saiki iki..)....( (Mau kerja dimana yang bisa menerima. Kerja di perusahaan perusahaan yo bayarane gak cukup buat makan. Buat bayar kost-kostan. Akhire yo nekad ngene iki mas. Yo Alhamdulilah nekad membawa berkah.)

3. Melakukan usaha harus serius (kerjoan opo ae harus diseriusi Mas. Ojo setengahsetengah.)

4. Mencintai Setiap Usaha yang dilakukan (..melakukan kerja kudu dicintai).

5. Kerja Keras. (....kerja keras iku modale. Sing penting nggak ngganggu uripe konco, nggak ngganggu uripe tonggo.

6. Semangat (...Yen iso tonggo-tonggo ndeso kono diajak merantau beno gak lontang lantung onok ndeso mainan HP ae. Arek jaman saiki iku ngerti beres ae, dolanan HP sepedaan kakehan gaya tapi nganggur.)

7. Kemampuan melakukan analisis Usaha dan dan tahu membaca kondisi pasar (..Gak menentu Mas. Bisa 4 kali kalau pas 
ramai. Bisa 3 kali paling minim ya 2 kali. saya mengambil untung minimal Rp 800 per kilogram. Jadi dia beli satu kilo botol plastik seharga $\mathrm{Rp} 4.100$ setelah dipres, dia jual ke pabrik minimal seharga $\mathrm{Rp} 4.900 / \mathrm{kg}$. untung memang sitik mas tapi yen iso kirim bisa kirim 3.000 - $4.000 \mathrm{~kg}$ perkirim satu truk. Bisnis pengepul barang rongsokan seperti plastik, besi, kaleng dan sejenisnya memang menjanjikan.)

8. Berani Menanggung Risiko (Risiko ya ada mas mergone yen tuku besi, aluminium barang-barang sing rusak iku kadang mung estimasi).

9. Niat yang kuat dan Optimis (niat yang kuat, ojo isin, ojo males, ojo wedi risiko, optimis, wes to rejeki di depan kita....)

\section{KESIMPULAN dan SARAN}

Logical Induction, Penelitian fenomenologis melihat secara dekat interpretasi individu tentang pengalamanpengalaman. Secara garis besar interpretasi wirausahawan masyarakat pengepul dan bandar barang bekas dan sebagai masyarakat yang berasal dari Madura di keputih adalah:

1. Mereka adalah orang yang mempunyai keberanian mencoba dan tekat yang kuat.

2. Mereka adalah orang perantau yang mempunyai mental yang kuat.

3. Mereka dalam setiap berusaha apapun bidangnya selalu dilakukan secara Telaten menghilangkan rasa rendah diri.

4. Mereka terkenal mempunyai jiwa yang melekat adalah orang yang selalu menjalankan kerja keras pantang meyerah dalam berusaha.

5. Mereka menjunjung tinggi adanya kerja sama dan hubungan baik yang selalu melekat kuat terutama dari masyarakat Madura.

6. Mereka tipe wirausaha yang tidak mudah menyerah pada nasib.

7. Mereka terkenal punya niat yang kuat dalam berusaha.

8. Walaupun mereka tidak mempunyai pendidikan formal yang tinggi mereka tetap menyadari bahwa untuk berusaha agar berhasil harus ada ilmu tentang strategi berusaha.

9. Mereka adalah tipe orang yang berani risiko karena harga barang rongsokan di pabrik juga bisa naik bisa turun.

10. Mereka mempunyai kemampuan membaca peluang dan selalu optimis untuk mengembangkan usaha-usaha lain.

11. Mereka berani menghadapi kegagalan atau pantang menyerah pada keadaan.

12. Karakter-karakter wirausaha yang melekat di komunitas para pengepul dan bandar sampah masyarakat Madura di wilayah tertentu.

13. Masyarakat yang telah mencapai status pengepul maupun bandar menunjukkan pola kerja kerasdisertai dengan kesabaran dan ketekunan, akan tetapi disisi lain pemulung sebagai produsen sangat diuntungkan karena tidak kesulitan mendapatkan bahan baku dan juga tidak diperlukan biaya pengadaan bahan baku.

\section{SARAN}

1. Mengembangkan program pemberdayaan untuk meningkatkan kesejahteraan masyarakat pemulung(melalui keterampilan buah tangan yang nantinya punya nilai jual tinggi).

2. Pemerintah dapat memberikan wadah atau tempat yang layak untuk pengepul barang bekas, membuka usaha dan melegalkan keberadaan pengepulan sampah, karena keberadaan pengepul dapat membantu program pemerintah terhadap lingkungan.

3. Memberikan bantuan modal dan pola pembinaan UMKM kepada masyarakat pengepul untuk meningkatkan usaha yang ditekuni karena pengempul merupakan usaha yang mendatangkan nilai ekonomis yang tinggi.

Pengepul diharapkan meningkatkan kemampuan usaha melalui kreativitas kewirausahaan karena mereka sudah mampu mempertahankan usaha yang ditekuni bertahun-tahun, dan orang madura 
mempunyai jiwa kekerabatan yang tinggi terutama rekan-rekan yang satu kampung asal.

\section{DAFTAR PUSTAKA}

Achmad Zubair, Nogard S. Mahendra \&Asrini 2011, Karakteristik sampah rumah tangga dikota makasar dan pospek perkembangannta.Jurnal Teknik Sipil Fakultas Teknik Universitas Hasanuddin Vol. 05 Desember 2011.

Amos Neolaka (2008). Kesadaran Lingkungan. Jakarta: PT Rin-eka Cipta dalam Jamanti Retno, 2014.

Buchari Alma, Hal 1-2, 2010, Kewirausahaan, Bandung: Penerbit Alfabeta.

Chandra, Budiman. (2006). Pengantar Kesehatan Lingkungan.EGC. Jakarta.

Emzir. 2016, Metode Penelitian Kualitatif Analisis Data, Jakarta: Rajawali Pers.

Madanitec. 2011.Komposter Model drum 80Ldalamhttp:// madanitec.com/kom poster-sampah/

Meredith, Geoffrey, G. 2002. Kewirausahaan: Teori dan Praktek. Jakarta: PPM.

Mifbakhuddin. 2010. Pengaruh Ketebalan Karbon Aktif Sebagai Media Filter Terhadap Penurunan Kesadahan Air Sumur Artetis. Ekplanasi. Vol 5. No.2. 2010:68-78

Novi Marliani 2014.Pemanfaatan Limbah Rumah Tangga (Sampah Anorganik) Sebagai Bentuk Implementasi Dari Pendidikan Lingkungan Hidup. Jurnal Formatif 4(2): 124-132, 2014 ISSN: 2088$351 X$.

Ruslan, R. 2006. Metode Penelitian Public Relations danKomunikasi.Jakarta: Raja Grafindo Persada.

Saputra, Sangga and Mulasari, Surahma Asti (2017) Pengetahuan, Sikap, dan Perilaku Pengelolaan Sampah pada Karyawan di Kampus. Jurnal Kesehatan Masyarakat, 11 (1). pp. 2227. ISSN 1978 - 0575.

Satker Puslitbang Permukiman.,2009 Laporan Akhir, Penerapan Teknologi Pengelolaan Sampah Kota Terpadu Berbasis 3R., Satker PuslitbangkimPU.

Sugiyono. 2017, Metode Penelitian Bisnis (Pendekatan Kuantitatif, Kualitatif, Kombinasi, dan R\&D), Bandung: Alfabeta.
Suparno, 2013, “Usaha Daur Ulang dan Produksi Kompos dari Pengelolaan Sampah TPA". Jurnal ORBITH. 9 (2). Juli ; 135-146.

Zimmerer, T.W., \& Scarborough, N.M. 1998.Essentials of Entrepreneurship and Small Bussiness Management.Second Ed. Prentice Hall.12.

----,2008, Laporan Akhir Penerapan Teknologi Pengolahan Sampah Kota Terpadu Berbasis 3R, Satker PuslitbangkimPU.

----,2008, Undang-Undang Republik Indonesia no. 18 tahun 2008, Pengelolaan Sampah, Menteri Hukum dan Hak Asasi Manusia RI, Lembaran Negara RI tahun 2008 no. 69,Jakarta.

----,2009, Direktorat Jendral Cipta Karya Direktorat Pengembangan Penyehatan Lingkungan Permukiman, Pedoman Operasi dan Pemeliharaan Prasarana dan Sarana Persampahan, Departemen PekerjaanUmum. 